\title{
PENERAPAN PROGRAM INTERPERSONAL COMMUNICATION TRAINING TERHADAP KEMAMPUAN KOMUNIKASI
}

\author{
Eva Gustiana ${ }^{1}$, Opah Ropiah ${ }^{2}$ \\ Pendidikan Guru Pendidikan Anak Usia Dini, STKIP Muhammadiyah Kuningan \\ Email: eva_psikologi@upmk.ac.id
}

\begin{abstract}
Abstrak
Tujuan penelitian ini adalah memperoleh gambaran apakah modul yang dirancang bisa digunakan untuk meningkatkan kemampuan komunikasi interpersonal ibu yang memiliki anak usia dini. Desain penelitian yang digunakan adalah Quasi experimental. Sampel penelitian adalah $10 \mathrm{ibu}$ yang memiliki anak usia dini. Alat ukur yang digunakan adalah kuesioner komunikasi interpersonal DeVito. Pengujian validitas alat ukur dilakukan dengan teknik construct validity. Hasil penelitian menunjukkan bahwa sebagian besar ibu menampilkan reaksi positif terhadap pelatihan dan menunjukkan peningkatan kelima aspek komunikasi interpersonal. Hal ini Berdasarkan hasil dari pre-post test skor total komunikasi interpersonal sebesar 0,005 ( $\mathrm{H}_{0}$ ditolak), pre-post test skor aspek openness sebesar 0,017 $\left(\mathrm{H}_{0}\right.$ ditolak), pre-post test skor aspek empathy sebesar 0,005 $\left(\mathrm{H}_{0}\right.$ ditolak), pre-post test skor aspek supportiveness sebesar 0,034 $\left(\mathrm{H}_{0}\right.$ ditolak), prepost test skor aspek positivenness sebesar $0,018\left(\mathrm{H}_{0}\right.$ ditolak), pre-post test skor aspek equality sebesar 0,020 ( $\mathrm{H}_{0}$ ditolak). Dari data tersebut menunjukkan bahwa $\mathrm{t}_{\text {hitung }}<\mathrm{t}_{\text {tabel, }}$, sehingga $\mathrm{H}_{0}$ ditolak, maka terdapat pengaruh pada aspek komunikasi interpersonal, openness, empathy, supportiveness, positivenness dan equality secara significant.
\end{abstract}

Kata Kunci: Komunikasi Interpersonal, Anak usia dini, Ibu

\begin{abstract}
The purpose of this study is to obtain an overview of whether the module designed can be used to improve the interpersonal communication skills of mothers who have early childhood. The research design used was Quasi experimental. The study sample was 10 mothers who had early childhood. The measuring instrument used is the DeVito interpersonal communication questionnaire. Testing the validity of the gauge is done by construct validity techniques. The results showed that most mothers displayed positive reactions to training and showed an increase in the five aspects of interpersonal communication. This is based on the results of the pre-post test total interpersonal communication score of 0.005 ( $\mathrm{HO}$ rejected), the pre-post test openness aspect score of 0.017 ( $\mathrm{HO}$ rejected), the pre-post test empathy aspect score of 0.005 (HO rejected), prepost test score for the aspect of supportiveness is 0.034 ( $H 0$ rejected), the positivenness aspect pre-post test score is 0.018 ( $\mathrm{HO}$ rejected), the equality pre-post test score is 0.020 (HO rejected). From these data indicate that tcount <ttable, so that $\mathrm{HO}$ is rejected, then there is a significant influence on aspects of interpersonal communication, openness, empathy, supportiveness, positiveness and equality.
\end{abstract}

Keywords: Interpersonal Communication, Early Childhood, Mother

(C) 2019 Eva Gustiana ${ }^{1}$, Opah Ropiah ${ }^{2}$ Under the license CC BY-SA 4.0

http://jurnal.upmk.ac.id/index.php/pelitapaud 


\section{PENDAHULUAN}

Orang tua adalah komponen keluarga yang terdiri dari ayah dan ibu, dan merupakan hasil dari sebuah pernikahan yang sah yang dapat membentuk sebuah keluarga. Peranan orang tua adalah bertanggung jawab dalam mendidik, mengasuh, dan membimbing anak-anaknya untuk mencapai tahapan tertentu yang menghantarkan anak untuk siap dalam kehidupan bermasyarakat. Menurut Shochib (1998) ada sembilan upaya orang tua yang diaktualisasikan terhadap penataan dalam mendidik, mengasuh dan membimbing, (1) lingkungan fisik, (2) lingkungan sosial internal dan eksternal, (3) pendidikan internal dan eksternal, (4) dialog atau komunikasi dengan anakanaknya, (4) suasana psikologis, (5) suasana psikologis, (6) sosiobudaya, (7) perilaku yang ditampilkan pada saat terjadinya "pertemuan" dengan anakanaknya, (8) kontrol terhadap perilaku anak-anaknya, (9) menentukan nilai-nilai moral kepada anak-anaknya. Orang tua mempunyai peran yang penting untuk memberikan bekal kepada anak agar mampu berinteraksi dengan cara yang bisa diterima masyarakat. Selain itu keluarga juga merupakan media awal anak belajar mengenai nilai-nilai moral, disiplin, tanggung jawab, dan nilai-nilai agama. Dengan pembelajaran tersebut anak diharapkan dapat berinteraksi dengan lingkungan dan mampu menerapkan nilai-nilai tersebut saat berada di lingkungan.

$$
\text { Menurut Shochib }
$$
mengatakan bahwa dialog (komunikasi) orang tua dengan anak membantu anak untuk mengembangkan diri. Berdasarkan penelitian yang pernah dilakukan oleh Yusuf (2012), menemukan bahwa pengaruh komunikasi interpersonal antara ibu asuh dan anak berpengaruh signifikan terhadap kemandirian. Menurut Rakhmat (2011), mengatakan komunikasi juga ditujukan untuk menumbuhkan hubungan sosial yang baik. Manusia adalah makhluk sosial yang tidak tahan hidup sendiri. Kita ingin berhubungan dengan orang lain secara positif. Abraham Maslow (1980: 80-92) menyebutkan "kebutuhan akan cinta" atau "belongingness". William Schuz (1966) merinci kebutuhan soal ini kedalam tiga inclusion, control affection. Kebutuhan sosial adalah kebutuhan untuk menumbuhkan dan mempertahankan hubungan yang memusatkan dengan orang lain dalam hal interaksi dan asosiasi, pengendalian dan kekuasaan, dan cinta serta kasih sayang. Secara singkat kita bergabung dan berhubungan dengan orang lain, kita ingin mengendalikan dan dikendalikan, dan kita ingin mencintai dan dicintai. 
Kebutuhan sosial ini hanya dapat dipenuhi dengan komunikasi interpersonal yang efektif.

Peneliti mendapat keluhan dari beberapa ibu tentang anaknya yang berkaitan dengan perilaku anak di sekolah Anak Usia Dini. Para ibu juga merasa kesulitan dalam mendidik dan membimbing anaknya di rumah. Para ibu tersebut sudah mencoba dengan berbagai cara mulai dengan cara berbicara secara halus (menasehati), berbicara secara keras dengan cara memarahi atau berteriak atau berkata kasar. Selain itu ibu juga menghukum anak dengan cara memukul atau mencubit, namun cara tersebut tidak berhasil. Reaksi anak ketika ibu bersikap seperti itu kadang diam saja dan terkadang melawan dan bahkan menangis sambil teriak-teriak. Berdasarkan keluhan ibu tersebut, peneliti kembali melakukan wawancara lebih lanjut dengan para ibu dan ada 10 orang ibu yang mengeluhkan hal yang sama.

Berikut adalah hasil wawancara peneliti mengenai keluhan dari 10 orang ibu yang anaknya sulit untuk diarahkan. Keluhan pertama yaitu ibu kurang menanggapi dengan senang hati ketika merespon apa yang dibicarakankan oleh anak. Keluhan kedua, ibu kurang memberikan respon terhadap setiap perilaku anak. Keluhan ketiga yaitu ketika ibu berbicara dengan anak, anak cenderung tidak mau mendengarkan dan bahkan si anak membantah. Keluhan keempat yaitu, ibu kurang bisa menerima saran atau masukan dari anaknya. Keluhan ibu yang kelima yaitu ketika ibu berbicara cenderung tidak konsisten kepada anaknya. Dilihat dari keluhankeluhan di atas peneliti menyimpulkan bahwa kemampuan ibu dalam berkomunikasi dengan anaknya cenderung kurang efektif. Dampak psikologis dari hasil wawancara di atas yaitu ibu merasa kebingungan karena tidak mengetahui cara agar anak mau mendengarkan apa yang disampaikannya, ibu merasa kecewa pada diri sendiri karena merasa kurang mampu dalam mendidik anak, ibu cenderung kurang mampu untuk mengontrol emosi ketika anak tidak mau mendengarkan/merespon apa yang disampaikan ibu (misalnya ibu menangis, marah, berkata kasar dan tidak segansegan memukul anaknya), dan ibu merasa bersalah karena hubungan ia dengan anaknya menjadi kurang baik. Menurut Rakhmat (2011) salah satu faktor yang mempengaruhi hubungan yang baik adalah komunikasi interpersonal yang baik.

Dilihat dari fenomena yang ada, 10 orang ibu kurang memiliki kemampuan dalam komunikasi interpersonal terhadap 
anaknya, dimana ibu kurang terbuka, kurang berempati terhadap anak, kurang bisa untuk memfasilitasi kebutuhan anak. Walaupun dengan keterbatasan ibu dalam berkomunikasi, ibu sudah mencoba untuk berbicara dengan baik (menasehati) kepada anak tetapi anak masih saja melakukannya sehingga Ibu menjadi mudah terpancing emosi dan tidak menyadari telah menyakiti perasaan anak dengan mengeluarkan kata-kata kasar, mencubit, memukul, bahkan meminta anak untuk pergi dari rumah, tak jarang juga ibu melampiaskan kemarahannya kepada anggota keluarga yang lain misalnya suami dan anak yang lainnya, sehingga hubungan ibu dengan anggota keluarga yang lain menjadi kurang baik, disisi lain ibu kurang fokus melakukan tugas rumah tangga, kepala sakit dan sulit untuk tidur.

Komunikasi interpersonal menurut Rakhmat (2011), adalah proses belajar yang terjadi pada dua orang. Hal ini dikarenakan komunikasi menjadi penting untuk pertumbuhan pribadi setiap individu. Kepribadian terbentuk sepanjang hidup kita. Melalui komunikasi kita menemukan diri kita, mengembangkan konsep diri, dan menetapkan hubungan dengan dunia di sekitar. Hubungan setiap individu dengan orang lain akan menentukan kualitas hidup individu tersebut. Berdasarkan hal ini maka peneliti tertarik untuk memberikan intervensi yang bertujuan untuk meningkatkan kemampuan komunikasi interpersonal ibu. Dalam kaitannya dengan penelitian ini, intervensi yang diberikan berupa pelatihan komunikasi interpersonal dalam bentuk experiential learning. Experiential learning merupakan model pembelajaran yang dimulai dengan mendapatkan pengalaman langsung yang diikuti dengan suatu pemikiran, diskusi, analisis dan evaluasi dari pengalaman tersebut (Weight, Albert, Participative Education and the Inevitable Revolution in journal of Creative Behavior, Vol 4, Fall 1970).

Melalui pemberian intervensi ini diharapkan para ibu yang memiliki anak usia dini dapat memanfaatkan proses pembelajaran yang diperolehnya sebagai bekal baginya dalam menjalin komunikasi interpersonal yang efektif dengan anaknya.

\section{METODE PENELITIAN}

Penelitian ini dilakukan dengan mengunakan pendekatan quasi experimental design, yaitu suatu penelitian yang memiliki bentuk menyerupai dengan eksperimen. Quasy Experimental biasanya digunakan ketika kontrol secara penuh tidak dimungkinkan seperti dalam penelitian eksperimental (Graziano and Laurin, 2000). Rancangan 
penelitian yang digunakan adalah one group before-after, (pretest-postest design) dimana akan dilihat perbedaan hasil test peserta sebelum dan sesudah pelaksanaan variabel independent.

Populasi penelitian ini adalah ibu dari anak usia usia pendidikan usia dini yang berjumlah 10 orang. Dengan karakteristik merupakan ibu dari anak usia pendidikan usia dini dan bersedia mengikuti pelatihan.

Program pelatihan komunikasi interpersonal disusun berdasarkan teori komunikasi interpersonal yang dikemukakan DeVito (1997) dengan menggunakan metoda experiential learning serta materi pelatihan yang berisi games, role playing, pemutaran video, simulasi dan diskusi. Komunikasi interpersonal yang menjadi fokus dalam penelitian ini adalah keterbukaan (openness), empati (empathy), sikap mendukung (supportiveness), sikap positif (positiveness) dan kesetaraan (equality).

\section{HASIL DAN PEMBAHASAN}

Dari hasil penelitian di atas bahwa penelitian ini bisa dilihat masing-masing aspek secara rinci, yaitu:

Terdapat peningkatan kemampuan komunikasi interpersonal pada para ibu setelah diberikan pelatihan komunikasi interpersonal. Hal ini tidak terlepas dari evaluasi reaksi peserta mengenai pelatihan Secara keseluruhan peserta menampilkan reaksi positif terhadap pelatihan komunikasi interpersonal ini. Reaksi positif tersebut berupa penghayatan bahwa secara keseluruhan pelatihan tersebut menarik, bermanfaat dan dapat diaplikasikan. Selain itu peserta juga menghayati ruangan dan fasilitas juga nyaman dan memadai, demikian juga waktu pelatihan juga dinilai cukup oleh para peserta. Reaksi peserta yang positif terhadap pelatihan membuat penilaian dan penghayatan tersebut berdampak pada penyerapan materi selama pelatihan, yang akhirnya berdampak pada peningkatan kemampuan komunikasi interpersonal para peserta setelah diberikannya pelatihan.

Reaksi peserta terhadap trainer dan fasilitator dalam pelatihan ini cenderung positif. Peserta menyatakan pemberi materi sangat menguasai materi, mampu menguasai kelas dan juga dapat menjelaskan materi dengan baik. Peserta memberikan respon yang positif mengenai trainer, yaitu dapat mejelaskan dan menyampaikan materi serta menguasai kelas dengan baik, membuat peserta dapat memahami materi yang diberikan, respon tersebut akhirnya berdampak pada peningkatan kemampuan komunikasi interpersonal 
peserta setelah mengikuti pelatihan komuniaksi interpersonal.

Peningkatan yang terjadi pada aspek empathy adalah yang paling tinggi. Peningkatan aspek empathy tersebut tidak terlepas dari reaksi positif peserta terhadap metode materi yang diberikan dalam pelatihan. Metode role playing yang digunakan untuk meningkatkan kemampuan empathy dalam berkomunikasi dengan anaknya dinilai sebagian besar peserta sebagai metode yang paling menarik dibandingkan dengan metode lainnya. Metode role playing yang digunakan tidak hanya dapat melatih keterampilan peserta dalam berkomunikasi dengan anaknya, namun juga dapat memahami perasaan anaknya ketika berkomunikasi dengan ibunya. Metode ini juga bermanfaat untuk melatih peserta dalam mengembangkan keterampilan interpersonal yang efektif. Pemilihan tema role playing yang merupakan situasi sehari-hari yang dihadapi peserta yaitu komunikasi antara ibu dan anak.

Aspek openness pada ibu yang telah mengikuti pelatihan komunikasi interpersonal juga mengalami peningkatan, meskipun peningkatannya lebih kecil jika dibandingkan dengan aspek empathy. Proses pembelajaran aspek openness tersebut berkaitan erat dengan reaksi peserta akan metode dan materi yang diberikan. Metode diskusi kasus dan pemilihan kasus yang digunakan berdasarkan pengalaman pribadi peserta yang dinilai menarik oleh para peserta juga. Ketertarikan mereka tersebut berdampak pada keaktifannya dan keseriusannya dalam mengerjakan tugas berupa studi kasus dalam bentuk tugas tertulis yang diberikan kepada para peserta. Peserta juga menilai bahwa materi yang diberikan bermanfaat dan dapat diaplikasikan. Penilaian dan penghayatan tersebut berdampak pada penyerapan materi opennes yang diberikan kepada para peserta, sehingga aspek opennes peserta meningkat (70\%) peserta meningkat. Melalui metode tugas tertulis dan diskusi kelompok tentang suatu kasus peserta dapat mengaplikasikan dan melatih keterampilan dalam aspek opennes-nya secara langsung. Selain itu pemilihan kasus yang berkaitan dan menggambarkan situasi sehari-hari yang mereka hadapi membuat peserta dapat berlatih secara langsung menyelesaikan kasus yang diberikan dengan adanya supervisi dari pemberi materi dan juga masukan dari rekan-rekannya saat diskusi kelompok. Metode tersebut dapat membuat peserta lebih mampu mengenali gejala permasalahan yang muncul, mengidentifikasi masalah yang dihadapi, memunculkan beberapa 
alternatif penyelesaian masalah, mengambil keputusan penyelesaian masalah dari beberapa alternatif penyelesaian masalah yan gada dengan mempertimbangkan konsekuensikonsekuensi yang mungkin terjadi dan membuat langkah awal untuk mewujudkan penyelesaian masalah yang dipilihnya. Hal ini terlihat dari adanya skor aspek opennes sebagian besar peserta $(70 \%)$ setelah diberikan pelatihan.

Peningkatan pada aspek positiveness dan aspek equality peserta tidak terlepas dari reaksi peserta akan metode dan materiyang diberikan. Dari hasil evaluasi level reaksi diperoleh bahwa peserta memberikan reaksi positif mengenai materi dan metode yang digunakan. Peserta menghayati metode simulasi atau game yang digunakan menarik, yang akhirnya membuat peseta ikut aktif dan antusias dalam mengikuti semua kegiatan dalam sesi tersebut. Materi positiveness dan equality yang diberikan juga dinilai bermanfaat dan dapat diaplikasikan oleh peserta. Metode games/simulasi yang digunakan bertujuan membuat peserta menyadari pentingnya memiliki aspek positiveness dan aspek equality dalam komunikasi interpersonal dengan anak. Metode games/simulasi yang didukung dengan respon positif peserta berdampak pada terjadinya peningkatan skor aspek positiveness dan aspek equality sebagian besar peserta $(80 \%)$ setelah diberikan pelatihan.

Peningkatan yang paling kecil adalah pada aspek supportiveness, yaitu $50 \%$ peserta, $20 \%$ mengalami penurunan dan $30 \%$ tidak mengalami perubahan setelah diberikan pelatihan. Hal ini berkaitan dengan proses pembentukan yang membutuhkan proses yang cukup panjang. Suatu pemahaman baru akan suatu hal tidak akan segera diadopsi oleh seseorang menjadi keyakinannya, namun membutuhkan pembuktian terlebih dahulu mengenai pemahaman tersebut, dan pembuktian ini harus berlangsung secara berulang-ulang hingga akhirnya individu yang bersangkutan mengadopsi pemahaman tersebut menjadi keyakinannya. Jika dibandingkan dengan pembelajaran yang dilakukan dalam pelatihan ini, para peserta hanya diberi kesempatan sekali untuk membentuk pemahaman atau keyakinan baru mengenai kontrol dan keyakinannya akan kemampuan yang dimilikinya, sedangkan untuk membuat peserta menginternalisasi keyakinan tersebut dibutuhkan pembelajaran dan pembuktian yang berulang-ulang, mungkin hal inilah yang menyebabkan peningkatan aspek supportiveness cenderung lebih kecil jika dibandingkan 
dengan empat aspek komunikasi interpersonal lainnya.

\section{SIMPULAN}

Berdasarkan hasil penelitian, maka dapat disimpulkan bahwa peningkatan kemampuan berkomunikasi ibu melalui pelatihan komunikasi interpersonal. Berdasarkan hasil dari program interpersonal communication traning ada pengaruh signifikan pada kemampuan berkomunikasi interpersonal ibu. Berdasarkan hasil rekapitulasi reaksi peserta terhadap pelatihan, tanggapan peserta pelatihan terhadap program Interpersonal communication training adalah $80 \%$ peserta mengatakan bahwa pelatihan tersebut sangat bermanfaat.

\section{DAFTAR PUSTAKA}

Anne, Anastasi. (1976). Psychological Testing. New York. Macmillan Publishing Co.,Inc

Aw, Suranto (2011). Komunikasi Intepersonal. Yogyakarta: Graha Ilmu

Azwar, Saifuddin M.A.(2005). Metode Penelitian. Yogyakarta. Pustaka Pelajar.

DeVito, Joseph. A. (1997). Komunikasi Antar manusia Edisi Kelima. Alih Bahas a oleh Ir.Agus Maulana MSM. Jakarta: Profesional Books.

Feldman, Olds, Papalia. (2009). Human Development. Edisi Sepuluh. Alih Bahasa oleh Brian Marwensdy. Jakarta: Salemba Humanika

Friedenberg, Lisa. (1995). Psychological Testinf: Design, Analysis, and Use.
Massachusetts: Allyn \& Bacon A Simon \& Schuster Company.

Gordon, Thomas. (1994). Menjadi Orangtua Efektif dalam Mendidik Anak yang Bertanggung jawab. Jakarta: Gramedia Pustaka

Graziano, Anthony. M. (2000). Research Methods: A Process of Inquiry. New York: Allyn \& Bacon.

Joni. (2013). Pengaruh Disiplin Belajar \& Komunikasi Interpersonal Keluarga Terhadap Hasil Belajar IPS Siswa Kelas VII SMP N 13 Padang. Melalui ejournal.unp.ac.id/students/index/p $\mathrm{hp} /$ pek/article/view.

Kirkpatrick, Donald L.(2006). Evaluating Training Program 2nd Edition. Berrete-Koehler Publisher. Inc. Boston.

Rakhmat, Jalaluddin. (2011). Psikologi Komunikasi. Bandung: PT. Remaja Rosdakarya.

Ramdhani, Rio. (2013). Komunikasi Interpersonal Orangtua dan Anak Dalam Membentuk Perilaku Positif Anak Pada Murid SDIT Corvoda Samarinda. Samarinda: Skripsi. Universitas Mulawarman

Rusyiyah. C. Aida. (2008). Efektivitas Penyuluhan Komunikasi Interpersonal Pada Ibu Dengan Anak Autistik di Lembang Study Autisme " $\mathrm{X}$ " Bandung. Tesis. Bandung: Universitas Kristen Maranatha.

Santrock. W. John. (2009). Life Span Development. Jilid I. Jakarta: Erlangga.

Schaefer, Charles. (1979). Bagaimana Mendidik dan Mendisiplinkan 
Anak, Alih Bahasa Oleh Drs. R. Turman Sirait \& Dr. Conny. Semiawan Medan: Kmpus IKIP Medan.

Silberman, Mel. (1990). Active Training, a Handbook of Techniques Designs, Case Example and Tips. New York: Lexingtong Books.

Shochib, Moh. (1998). Pola Asuh Orang Tua untuk Membantu Anak Mengembangkan Disiplin Diri. Jakarta: Rineka Cipta

Sugiono, (2013). Statistik Nonparametris. Bandung. CV. Alfabeta

Walter GA, Marks SE. (1981). Experiential Learning and Change: theory, design and practice. New York.

Weight, Albert. (1970). Participative Education and The Inevitable Revolution. Journal of Creative Behavior, Vol 4, pp 234-282.

Wiryanto. (2004). Pengantar Ilmu Komunikasi. Jakarta : PT. Grasindo

Wisnuwardhani, Dian \& Mashoedi. F. Sri. (2012). Hubungan Interpersonal. Jakarta : Salemba Humanika.

Yusuf, Elvina. (2012). Efektivitas Komunikasi Interpersonal Antara Orang Tua dengan Anak panti Asuhan dalam Meningkatkan Kemandirian Anak. Melalui: http://pat.trunojoyo.ac.id/welcomed etail/090531100021 